\title{
Production and Grower Preference of Potato in Northern Zone of Bangladesh: Scenario from Shibgonj, Bogra and Kalai, Joypurhat
}

\author{
Md. Anower Hossain ${ }^{1}$, Shakil Arvin Zomo², Ahsan Ullah ${ }^{3}$, Sheikh Mohammad \\ Shakilur Rahaman and Md. Dulal Sarkar ${ }^{4} *$
}

Namuja Degree College, Bogra ${ }^{1}$

Department of Agriculture Extension, Dhaka ${ }^{2}$

Monshir Hat Prokowshali Oahidur Rahoman Degree College, Comilla ${ }^{3}$

Dept. of Horticulture, Sher-e-Bangla Agricultural University, Dhaka, Bangladesh ${ }^{4}$

*Corresponding author: dulalsau_121@yahoo.com

\begin{abstract}
This study was conducted during 2010-11 in northern zone of Bangladesh to highlight the current status and the importance of potato farming. About 120 respondents were randomly selected for interviewing and collecting data from Shibganj of Bogra and Kalai of Joypurhat district. The selection characteristics for the respondents were age, education, experience, farm size, family size and annual income. These six characteristics of the farmers were selected for exploring their relationship with their growing preference and production scenario of potato. Age of the potato growers ranged from 27 to 65 years, $20.8 \%$ of the farmers was illiterate and most of them have a small family and medium sized farm. About $16.5 \%$ farmers have low income up to BDT. 120,000 while $20.8 \%$ farmers have an income higher than BDT. 250,000 year $^{-1}$. Farmers were interested to cultivate the potato due to higher yield and greater profit making than other crops and, they preferred Diamant as the most profitable variety.
\end{abstract}

Key words: Potato, profitable variety, socio-economic characteristics, use pattern

\section{Introduction}

Potato (Solanumtuberosum L.) is the most important vegetable crop in Bangladesh. Bangladeshi vegetable basket is incomplete without potato. It contributes $55 \%$ of the total vegetable production in Bangladesh (BBS 2009). It is ranked third among the food crops next to rice and wheat on the basis of production. The average yield and total production of potato is about $14.7 \mathrm{t} \mathrm{ha}^{-1}$ and 9.0 million tons, respectively from 0.5 million hectares of land (MOA 2009). Bogra and Joypurhat districts contribute nearly $8 \%$ of the total potato production occupying $10.7 \%$ of the land surface. The main producing areas are Kalai, Khetlal, Bograsadar, Shibganj and Gabtali upazila (Rahman 1990). Area covers under potato cultivation in Bogra and Joypurhat districts about $77 \%$ of the total cultivated area (Uddin et al., 2009). Latest information on potato production in northern part of Bangladesh is limited. So, it is necessary to quantify the potato production scenario in these areas. Therefore, the present study was designed to identify the growing preference and production scenario in two northern districts of Bangladesh.

\section{Materials and Method}

There were 51 blocks, 17 unions in two selected upazilas viz. Shibgonj of Bogra and Kalai of Joypurhat district. 60 farmers from each upazilla were randomly selected and total 120 respondents 
were interviewed regarding collecting primary data and information during 2010-11. Data were collected by the direct supervision of farmers and discussion with them. Incase of any inconsistency, data were rechecked and corrected through repeated visits.

\section{Results and Discussion}

\section{Socio-economic characteristics of farmers}

Different farmers possess different characteristics. The selected characteristics of the farmers were; age, education, experience in potato cultivation, farm size, family size and annual income. Six characteristics of the farmers with their relationships in potato cultivation are presented in table 1.

Table 1. Characteristics profile of the respondents

\begin{tabular}{lcccc}
\hline \multirow{2}{*}{ Characteristics } & Measured by & \multicolumn{2}{c}{ Actual value } & \multirow{2}{*}{$\begin{array}{c}\text { Mean } \\
\text { value }\end{array}$} \\
\cline { 3 - 4 } & & Minimum & Maximum & \\
\hline Age & Year & 27 & 65 & 40.9 \\
Education & Scoring & 0 & 14 & 7.0 \\
Experience & Year & 5 & 32 & 18.1 \\
Farm size & Hectare & 0.5 & 3.3 & 1.4 \\
Family size & Person & 3 & 9 & 4.3 \\
Annual income & Taka ('000') & 46 & 310 & 162.3 \\
\hline
\end{tabular}

The minimum age of the respondents was 27 years and maximum was 65 years with mean value of 40.9. Education level was scoring according to passing years in which " 0 " means no education of the respondents and 14 mean graduate level educations. Experiences in potato cultivation of the respondents were minimum 5 years and maximum 32 years. Maximum farmers of two districts are categorized as medium andtheir annual income ranges from 46 to 310 thousands taka only.

\section{Age of the respondents}

Most of the farmers (52.5\%) in Shibganj and Kalai upazilas were in the age group of 35-50 years. The highest aged group (35-50 years) of farmers about $48 \%$ was in Shibganj upazila followed by the young farmers (30\%). The maximum number of old farmers were engaged in potato farming than the young group in all study areas where the old was about $27.5 \%$ and the young farmers was $20 \%$ (Table 2). About one-fourth of the old farmers in both upazilas were engaged in potato farming might be due to many young farmers had been working in foreign countries and also engaged in others work.

Table 2. Classification of the farmers according to their age

\begin{tabular}{lccccccc}
\hline \multirow{2}{*}{ Categories } & \multirow{2}{*}{$\begin{array}{c}\text { Age } \\
\text { (Years) }\end{array}$} & \multicolumn{2}{c}{ Shibganj upazila } & \multicolumn{2}{c}{ Kalai upazila } & \multicolumn{2}{c}{ Overall areas } \\
\cline { 3 - 8 } Young & Up to 34 & 18 & 30 & 06 & 10 & 24 & 20 \\
Middle & 35to 50 & 29 & 48 & 34 & 57 & 63 & 52.5 \\
\multirow{2}{*}{ Old } & Above 50 & 13 & 22 & 20 & 33 & 33 & 27.5 \\
& Total & 60 & 100 & 60 & 100 & 120 & 100 \\
\hline
\end{tabular}




\section{Level of education}

About 22\% and 28\% farmers in Shibganj and Kalai upazila, respectively completed primary school education. Majority farmers (38\%) of Shibganj and Kalai upazilacompleted secondary school education. The notable numbers of farmers $(16 \%)$ in Shibganj and Kalaiupazila were completed above secondary level education. This might be due to relatively young farmers were engaged in potato cultivation commercially. The level of illiterate farmers in Shibganj and Kalai upazila was lower because, the level of literacy in both areas was found higher (79\%) than the average literacy of Bangladesh (Table 3).About 63\% farmers among the total respondents in the study areas were reached up to the primary and secondary level of education. Generally during this period, fathers or guardians of a family gave the charge of their family and lands to their elder sons and thus they could not further continue their higher education. Sometimes they were forced to leave school and engaged in family farming due to economic crisis.

Table 3. Classification of the farmers according to their education

\begin{tabular}{|c|c|c|c|c|c|c|c|}
\hline \multirow{2}{*}{ Categories } & \multirow{2}{*}{$\begin{array}{l}\text { Level of } \\
\text { Education }\end{array}$} & \multicolumn{2}{|c|}{$\begin{array}{c}\text { Farmers of } \\
\text { Shibganj upazila }\end{array}$} & \multicolumn{2}{|c|}{$\begin{array}{c}\text { Farmers of } \\
\text { Kalai upazila }\end{array}$} & \multicolumn{2}{|c|}{ Overall areas } \\
\hline & & Number & $\%$ & Number & $\%$ & Number & $\%$ \\
\hline No education & $\begin{array}{l}\text { Unable to read } \\
\text { and write }\end{array}$ & 12 & 20 & 13 & 22 & 25 & 21 \\
\hline Primary education & Class I to V & 13 & 22 & 17 & 28 & 30 & 25 \\
\hline Secondary education & Class VI to X & 25 & 41 & 21 & 35 & 46 & 38 \\
\hline Above secondary education & Above class $\mathrm{X}$ & 10 & 17 & 09 & 15 & 19 & 16 \\
\hline Tota & & 60 & 100 & 60 & 100 & 120 & 100 \\
\hline
\end{tabular}

\section{Experience in potato cultivation}

On the basis of respondent's experience, farmers were classified into three categories. The maximum farmers $(70.8 \%)$ had moderate experience about 11to 25 years in potato cultivation (Table 4 ).

Table 4. Classification of the farmers according to their experience in potato cultivation

\begin{tabular}{lccc}
\hline \multirow{2}{*}{ Categories } & \multirow{2}{*}{$\begin{array}{c}\text { Experience } \\
\text { (Years) }\end{array}$} & \multicolumn{2}{c}{ Farmers } \\
\cline { 3 - 4 } & Up to 10 & 16 & 13.3 \\
Low experience & 11 to 25 & 85 & 70.8 \\
Medium experience & Above 25 & 19 & 15.8 \\
High experience & & 120 & 100 \\
& & &
\end{tabular}

\section{Farm size}

Farm size of the respondents ranges between 0.54 and 3.3 hectare. Based on farm size, the farmers were categorized into three groups. The maximum farmers $(65 \%)$ had medium size farm while only $5.8 \%$ farmers had large farm (Table 5). 
Table 5. Classification of the farmers according to their farm size

\begin{tabular}{lccccccc}
\hline \multirow{2}{*}{ Categories } & \multirow{2}{*}{$\begin{array}{c}\text { Farm size } \\
\text { (ha) }\end{array}$} & \multicolumn{2}{c}{$\begin{array}{c}\text { Farmers of } \\
\text { Shibganj upazila }\end{array}$} & \multicolumn{2}{c}{$\begin{array}{c}\text { Karmers of } \\
\text { Kalai upazila }\end{array}$} & \multicolumn{2}{c}{ Overall areas } \\
\cline { 2 - 8 } & Number & $\%$ & Number & $\%$ & Number & $\%$ \\
\hline Small & Up to 1 & 20 & 33.3 & 15 & 25 & 35 & 29.1 \\
Medium & 1.1 to 3 & 37 & 61.6 & 41 & 68.3 & 78 & 65 \\
Large & Above 3 & 3 & 5 & 4 & 6.6 & 7 & 5.8 \\
& Total & 60 & 100 & 60 & 100 & 120 & 100 \\
\hline
\end{tabular}

\section{Family size}

Family size of the farmers ranges from 3 to 9 person with an average of 4.3 members per family and this was smaller than average family size of Bangladesh (5.1) member per family; (BBS, 2011). The maximum farmers (63.3\%) live in a small family of the study areas, on the other hand only $4.1 \%$ farmers had large family (greater than 7 members). The findings indicate that $95.8 \%$ of the potato growing farmers had small to medium size family (Table 6).

Table 6. Classification of the farmers according to their family size

\begin{tabular}{lccc}
\hline \multirow{2}{*}{ Categories } & $\begin{array}{c}\text { Family size } \\
\text { (person) }\end{array}$ & \multicolumn{2}{c}{ Farmers } \\
\cline { 3 - 4 } Small & Up to 4 & 76 & 63.3 \\
Medium & 5 to 7 & 39 & 32.5 \\
Large & Above 7 & 5 & 4.1 \\
& Total & 120 & 100 \\
\hline
\end{tabular}

\section{Annual income}

Annual income of the farmers ranges from 46 to 310 thousand taka. Overall in the study areas, the highest portion of the respondents (51.6\%) had medium income followed by low (27.5\%) and high (20.8\%) income earners. Generally higher income gives an individual better status in the society but higher income also increases risk taking capacity of the farmers in potato cultivation.

Table 7. Classification of the farmers according to their annual income

\begin{tabular}{lccc}
\hline \multirow{2}{*}{ Categories } & \multirow{2}{*}{ Annual } & \multicolumn{2}{c}{ Farmers } \\
\cline { 3 - 4 } & income('000'Tk) & Number & $\%$ \\
\hline Low & Up to 120 & 33 & 16.5 \\
Medium & 121 to 250 & 62 & 51.6 \\
High & Above 250 & 25 & 20.8 \\
& Total & 120 & 100 \\
\hline
\end{tabular}

\section{Postharvest using pattern of potato}

In Kalai upazila, family farm produces the highest quantity of potato $\left(30.8 \mathrm{t}^{\text {year }}{ }^{-1}\right)$ than Shibganj upazila. This might be due to higher yield and using more HYV in Kalai upazila than that of Shibganj upazila. Average potato productions per farm were $27.3 \mathrm{t}$ in the study area. In overall areas, about $1.6 \%$ of the potatoes were used for family consumption by the potato growers and $3.2 \%$ of the potatoes 
were used as seed. Major portions $(69.2 \%)$ of the potatoes were sold during the harvesting period (Table 8). About $9.9 \%$ and $15.9 \%$ of the potatoes were traditionally stored in house and cold storage, respectively. The potatoes were stored in house or cold storage for planting as seed for the next season or as ware potato and sold later an exorbitant price. Average potato production farm ${ }^{-1}$ in Shibganj upazila was $23.8 \mathrm{t}^{\text {year }}{ }^{-1}$. About $1.7 \%, 4.3 \%, 72.2 \%$ and $21.6 \%$ of the potatoes were used for family consumption, seed purpose, and direct sale during harvesting time and were stored in home or cold storage, respectively for sale or seed purpose. On the other hand, Postharvest potatoes were used as food $(1.5 \%)$, seed $(2.2 \%)$, home storage $(12.2 \%)$, cold storage $(17.8 \%)$ and direct sale $(66.1 \%)$ during harvesting period in Kalai upazila (Table 8).

Table 8. Postharvest use pattern of potato

\begin{tabular}{lcccccc}
\hline \multirow{2}{*}{ Using pattern } & \multicolumn{2}{c}{ Shibganj upazila } & \multicolumn{2}{c}{ Kalai upazila } & \multicolumn{2}{c}{ Overall areas } \\
\cline { 2 - 7 } & $\begin{array}{c}\text { Production } \\
\left(\mathrm{t} \mathrm{year}^{-1}\right)\end{array}$ & $\begin{array}{c}\text { Use } \\
(\%)\end{array}$ & $\begin{array}{c}\text { Production } \\
\left(\mathrm{t} \text { year }^{-1}\right)\end{array}$ & $\begin{array}{c}\text { Use } \\
(\%)\end{array}$ & $\begin{array}{c}\text { Production } \\
\left(\mathrm{t} \mathrm{year}^{-1}\right)\end{array}$ & $\begin{array}{c}\text { Use } \\
(\%)\end{array}$ \\
\hline Food & 0.4 & 1.7 & 0.4 & 1.5 & 0.4 & 1.6 \\
Seed & 1.0 & 4.3 & 0.6 & 2.2 & 0.8 & 3.2 \\
Sale & 17.2 & 72.2 & 20.4 & 66.1 & 18.8 & 69.2 \\
Home storage & 1.8 & 7.5 & 3.7 & 12.2 & 2.7 & 9.9 \\
Cold storage & 3.3 & 14.1 & 5.5 & 17.8 & 4.4 & 15.9 \\
Total & 23.8 & 100 & 30.8 & 100 & 27.3 & 100 \\
\hline
\end{tabular}

\section{Land use, average wholesale price and yield of potato}

Areas under potato cultivation gradually increased during the period from 2008 to 2010 but it decreased in 2011. The average wholesale price was higher in 2009 than those of 2010 and 2011. The average potato yield increased in 2010 and 2011 by $9.7 \%$ and $3.7 \%$, respectively, compared to that of 2009 (Table 9). It reveals that, land use for potato cultivation was higher when the average wholesale price was higher in the previous year and when the average yield of potato was lower, then the average wholesale price was higher. When the average wholesale prices fell, then the potato growers did not want to invest any more in the next season. It is a significant draw backs to sustain potato cultivation and this volatile market price is a big challenge for potato growers.

Table 9. Comparative study of land use for potato cultivation, average wholesale price and yield during 2008 to 2011

\begin{tabular}{|c|c|c|c|c|}
\hline \multirow{2}{*}{ Particulars } & \multicolumn{4}{|c|}{ Year } \\
\hline & 2008 & 2009 & 2010 & 2011 \\
\hline Land use for potato cultivation (ha farm ${ }^{-1}$ ) & 1.6 & $\begin{array}{c}1.6 \\
(+3.7 \%)\end{array}$ & $\begin{array}{c}1.7 \\
(+4.8 \%)\end{array}$ & $\begin{array}{c}1.5 \\
(-10.9 \%)\end{array}$ \\
\hline Average wholesale price $\left(\mathrm{Tk} \mathrm{kg}^{-1}\right)$ & - & 6.1 & $\begin{array}{c}5.0 \\
(-18.1 \%)\end{array}$ & $\begin{array}{c}5.3 \\
(+10.9 \%)\end{array}$ \\
\hline Average yield of potato $\left(\mathrm{mt} \mathrm{ha}^{-1}\right)$ & - & 19.5 & $\begin{array}{c}21.3 \\
(+9.7 \%)\end{array}$ & $\begin{array}{c}22.1 \\
(+3.7 \%)\end{array}$ \\
\hline
\end{tabular}

\section{Profitable variety of potato}

Overall in the study areas, the highest benefit cost ratio was 1.3 for the variety called Diamant and the lowest was for the Granola (1.0). The highest average output ha ${ }^{-1}$ was for the variety Diamant too and the lowest for the Granola. The highest average input $\mathrm{ha}^{-1}$ was for the variety of Telpakri and the lowest for Granola (Table 10). 
Table 10. Profitable variety of potato

\begin{tabular}{lccccc}
\hline \multicolumn{1}{c}{ Variety } & $\begin{array}{c}\text { Output } \\
\left({ }^{\prime} 000{ }^{\prime} \mathrm{Tk} \mathrm{ha}^{-1}\right)\end{array}$ & $\begin{array}{c}\text { Input } \\
\left({ }^{\prime} 000{ }^{\prime} \mathrm{Tk} \mathrm{ha}^{-1}\right)\end{array}$ & $\begin{array}{c}\text { Profit } \\
\left({ }^{(} 000{ }^{\prime} \mathrm{Tkha}^{-1}\right)\end{array}$ & BCR & Rank \\
\hline Diamant & 107.9 & 83.0 & 25.8 & 1.3 & 1 \\
Lalpakri & 102.6 & 82.9 & 21.6 & 1.2 & 2 \\
Hagrai & 96.2 & 82.6 & 13.5 & 1.1 & 3 \\
Cardinal & 92.9 & 82.9 & 21.6 & 1.1 & 4 \\
Telpakri & 91.7 & 83.9 & 7.8 & 1.0 & 5 \\
Suriyamukhi & 86.1 & 81.0 & 5.0 & 1.0 & 6 \\
Alvery & 79.6 & 77.0 & 2.6 & 1.0 & 7 \\
Granola & 78.0 & 76.3 & 1.7 & 1.0 & 8 \\
\hline
\end{tabular}

\section{Source of financial support for potato cultivation}

Smalland medium farm groups managed their financial support for potato cultivation by taking loan from various source except large farm groups. Average loan taking of various farm groups was 11.4\% of total respondents(Table 11).Large farm group managed their cost for potato cultivation without taking any loan from other sources while small and medium farm group taking loan about $25 \%$ and $9.3 \%$, respectively for potato cultivation from various source (Table 11). They repay their loan after the harvest by selling potato at low price during harvest period. Generally higher income group leads a better status in the society. Therefore, the large farm group has the risk taking capacity of the farmers in potato cultivation. So they did not take any loan for this purpose.

Table 11. Source of financial support for potato cultivation

\begin{tabular}{lcccccc}
\hline \multirow{2}{*}{ Farm size } & \multicolumn{2}{c}{ Shibganj upazila $(\%)$} & \multicolumn{2}{c}{ Kalai upazila(\%) } & \multicolumn{2}{c}{ Overall areas (\%) } \\
\cline { 2 - 7 } & Loan & Own & Loan & Own & Loan & Own \\
\hline Small & 26.5 & 73.5 & 23.5 & 76.5 & 25 & 75 \\
Medium & 8.7 & 91.2 & 10 & 90 & 9.3 & 90.6 \\
Large & 0 & 100 & 0 & 100 & 0 & 100 \\
Average & 11.7 & 88.2 & 11.1 & 88.8 & 11.4 & 88.5 \\
\hline
\end{tabular}

\section{Why farmersare growingpotato?}

Opinions of the respondents were collected to interpret causes of growingpotato. Score (1) was assigned for one opinion by one respondent. The farmers were interested to grow potato because of higher profit, easier to grow, greater market demand and higher yield than other crops and suitable growing region. Potato growing region option stood as the $1^{\text {st }}$ ranked (Table 12). 
Table 12.Causes of growing potato

\begin{tabular}{lccccccc}
\hline \multirow{2}{*}{ Particulars } & \multicolumn{2}{c}{ Shibganj upazila } & \multicolumn{2}{c}{ Kalai upazila } & \multicolumn{2}{c}{ Overall areas } & \multirow{2}{*}{ Rank } \\
\cline { 2 - 7 } & Score & $\%$ & Score & $\%$ & Score & $\%$ & \\
\hline Potato growingregion & 26 & 43.3 & 27 & 45 & 53 & 44.1 & 01 \\
High yield thanothers & 21 & 35 & 24 & 40 & 45 & 37.5 & 02 \\
Profitable & 7 & 11.6 & 5 & 8.3 & 12 & 10 & 03 \\
Huge demand & 5 & 8.3 & 4 & 6.6 & 9 & 7.5 & 04 \\
Easy growing & 1 & 1.6 & 0 & 0 & 1 & 0.8 & 05 \\
If others & 0 & 0 & 0 & 0 & 0 & 0 & - \\
Total & 60 & 100 & 60 & 100 & 120 & 100 & \\
\hline
\end{tabular}

\section{Potato consumption and marketing}

The highest potato was used for consumption and seed purpose about $8.6 \%$ by small farm group that was followed $5.1 \%$ and $2.5 \%$ by medium and large farm group, respectively. Large farm group marketing the highest amount of potato about $97.4 \%$ and the average potato marketing $94.5 \%$ by all farm groups (Table 13).

Table 13. Potato consumption and marketing by different farm size

\begin{tabular}{lcccc}
\hline \multirow{2}{*}{ Farm size } & \multicolumn{2}{c}{ Purpose } & \multicolumn{2}{c}{ Marketing pattern } \\
\cline { 2 - 5 } & $\begin{array}{c}\text { Consumption and } \\
\text { seed (\%) }\end{array}$ & Marketing(\%) & $\begin{array}{c}\text { Direct sell } \\
(\%)\end{array}$ & $\begin{array}{c}\text { Through } \\
\text { middle-men (\%) }\end{array}$ \\
\hline Small & 8.6 & 91.3 & 37.3 & 62.6 \\
Medium & 5.1 & 94.8 & 47.3 & 52.6 \\
Large & 2.5 & 97.4 & 52.3 & 47.6 \\
Average & 5.4 & 94.5 & 45.6 & 54.3 \\
\hline
\end{tabular}

Marketingpattern of potato in these areas wereabout $37.3 \%$ and $62.6 \%$ direct sell and through middlemen, respectively by small farm group. The average marketing pattern by all farm groups was $45.6 \%$ direct sell and 54.3\% through middle-men (Table 13).

\section{Alternative crops rather than potato}

Respondents gave opinions on identifying an alternative crop rather than potato and one (1) score was assigned for one opinion. Themost wanted alternative crops rather than potato wasmustard and theleast wanted crop was teasle gourd during 2010-11 (Table 14). 
Table 14. Alternative crops rather than potato

\begin{tabular}{lccccccc}
\hline \multirow{2}{*}{$\begin{array}{l}\text { Alternative } \\
\text { crops }\end{array}$} & \multicolumn{2}{c}{ Shibganj upazila } & \multicolumn{2}{c}{ Kalai upazila } & \multicolumn{2}{c}{ Overall areas } & \multirow{2}{*}{ Rank } \\
\cline { 2 - 6 } & Score & Rank & Score & Rank & Score & $\%$ & \\
\hline Mustard & 17 & 1 & 27 & 1 & 44 & 36.6 & 1 \\
Maize & 12 & 3 & 13 & 2 & 25 & 20.6 & 2 \\
Wheat & 07 & 4 & 11 & 3 & 18 & 15 & 3 \\
Cucumber & 13 & 2 & 02 & 5 & 15 & 12.5 & 4 \\
Bottle gourd & 05 & 5 & 03 & 4 & 08 & 6.6 & 5 \\
Ash gourd & 03 & 6 & 02 & 5 & 05 & 4.1 & 6 \\
Brinjal & 02 & 7 & 01 & 6 & 03 & 2.5 & 7 \\
Teasle gourd & 01 & 8 & 01 & 6 & 02 & 1.6 & 8 \\
If others & 0 & - & 0 & - & 0 & - & - \\
Total & 60 & & 60 & & 120 & 100 & \\
\hline
\end{tabular}

\section{Preference of growing vegetables on the basis of importance}

Score, one (1) was assigned for one opinion of the respondents. Every respondent gave opinions according to importance of vegetable and potato was the most preferable vegetable and the least preferable vegetable was Spinach (Table 15).

Table 15. Preference of growing vegetables according to their importance

\begin{tabular}{lccc}
\hline \multicolumn{1}{c}{ Vegetables } & Score & Percentage & Rank \\
\hline Potato & 118 & 35.3 & 1 \\
Brinjal & 65 & 19.4 & 2 \\
Teasle gourd & 47 & 14.0 & 3 \\
Cucumber & 26 & 7.7 & 4 \\
Tomato & 16 & 4.7 & 5 \\
Bottle gourd & 13 & 3.8 & 6 \\
Amaranth & 08 & 2.4 & 7 \\
Pumpkin & 07 & 2.1 & 8 \\
Okra & 07 & 2.1 & 8 \\
Red amaranth & 06 & 1.8 & 9 \\
Swamp Cabbage & 05 & 1.5 & 10 \\
Bean & 05 & 1.5 & 10 \\
Indian spinach & 03 & 0.8 & 11 \\
Bitter gourd & 03 & 0.8 & 11 \\
Aroid & 03 & 0.8 & 11 \\
Spinach & 02 & 0.6 & 12 \\
Other if any & - & - & - \\
Total & 334 & 100 & \\
\hline
\end{tabular}

Among the vegetables, the preference for growing vegetable crops were in the order (from top to bottom) of potato, brinjal, teasle gourd, cucumber, tomato, bottle gourd, amaranth, pumpkin and okra 
$\left(8^{\text {th }}\right)$, red amaranth $\left(9^{\text {th }}\right)$, swamp cabbage and bean $\left(10^{\text {th }}\right)$, bitter gourd, aroid and indian spinach $\left(11^{\text {th }}\right)$, and spinach $\left(12^{\text {th }}\right)$ during $2010-11$.

\section{Conclusion}

Northern zone is one of the prominent regions for potato cultivation especially Bogra and Joypurhat districts. The maximum number of old farmers was engaged in potato farming. Most of the farmers completed primary and secondary level education and literacy percentage of these areas was higher than national level. Farmers sold major portion of their produced potato during the harvesting period. They used most of the land for potato cultivation when got higher wholesale price in the previous year. Diamant was cultivated by the farmers as the most profitable variety of potato and they were interested to grow potato because of higher yield than other crops.

\section{References}

BBS. (2011). Bangladesh Bureau of Statistics. Yearbook of Agricultural Statistics of Bangladesh.Statistics Division, Ministry of Planning, Government of the People's Republic of Bangladesh.

BBS. (2009). Bangladesh Bureau of Statistics.Yearbook of Agricultural Statistics of Bangladesh.Ministry of Planning, Government of the People's Republic of Bangladesh.p. 64.

MOA. (2009). Hand Book of Agricultural Statistics.Market Monitoring and Information System, Ministry of Agriculture (MOA), Govt. People's Repub. Bangladesh. p. 493.

Rahman, A. (1990). CGPRT centre, Regional Co-ordination Centre for Research and Development of Coarse Grains, Pulses, Roots, Tuber Crops in the Humid Tropics of Asia Pacific.

Uddin, M. A., Alam, Q. M. and Baset, M. A. (2009). Potato for food security in Bangladesh.Int. J. Sust. Crop Prod., 2004-2011. Green World Foundation (GWF), Canada.

\section{Citation for this article (APA Style)}

Hossain, M. A., Zomo, S. A., Ullah, A., Rahaman, S. M. S. \& Sarkar, M. D. (2014). Production and Grower Preference of Potato in Northern Zone of Bangladesh: Scenario from Shibgonj, Bogra and Kalai, Joypurhat. Journal of Bioscience and Agriculture Research,01(02), 93-101. Retrieved September 22, 2014, from http://www.journalbinet.com/current-issue.html. 